Cite this: CrystEngComm, 2013, 15, 1421

Received 19th October 2012,

Accepted 12th December 2012

DOI: $10.1039 / \mathrm{c} 2 \mathrm{ce} 26718 \mathrm{~g}$

www.rsc.org/crystengcomm

\section{Hydrogen bonding interactions and supramolecular networks of pyridine-aryl based thiosemicarbazides and their $\mathrm{Zn}(\mathrm{II})$ complexes $\dagger$}

\author{
Komala Pandurangan, Jonathan A. Kitchen, Thomas McCabe \\ and Thorfinnur Gunnlaugsson*
}

\begin{abstract}
The synthesis of five pyridyl derived thiosemicarbazides, $\mathbf{1 - 5}$, is presented. All five were formed in a single step from 2-hydrazinopyridine with commercially available isothiocyanates using microwave assisted synthesis. Compounds 1-4 were structurally characterised by single crystal diffraction analysis, and showed extended supramolecular hydrogen bonding arrays. Furthermore, the Zn(॥) complexes $\mathbf{6}$ and $\mathbf{7}$ have been prepared using ligands $\mathbf{1}$ and $\mathbf{5}$, and structurally characterised, again showing elegant assemblies of metalsupramolecular structures with solvent accessible channels, demonstrating that these building units are excellent candidates for use in supramolecular chemistry and crystal engineering.
\end{abstract}

\section{Introduction}

The investigation of self-assembly processes in supramolecular chemistry and crystal engineering between 'purely' organic molecules (i.e. not metal directed systems such as in $\mathrm{MOF}_{\mathrm{S}}$ ) has become an active area of research in recent times. ${ }^{1}$ Such systems rely mainly on short contact van der Waals, hydrogen bonding, ${ }^{2} \pi-\pi$ interactions, ${ }^{3}$ as well as $\mathrm{C}-\mathrm{H} \cdots \pi$ interctions. ${ }^{4}$ The interactions between hydrogen bonding donors and organic anions has also been explored for the formation of such self-assembly systems. ${ }^{5}$ Hydrogen bonding is a particularly powerful building motif for use in crystal engineering ${ }^{6}$ and a great variety of hydrogen bonding donors-acceptors exists, making them a particularly good choice for the construction of self-assemblies. Hydrogen bonds provide unique directionality, they are usually easily introduced into structures and their numbers can be varied through simple design; all of which can facilitate the formation of highly stable host-guest complexes (or conjugates) as recently demonstrated by Leigh and Hunter et al. ${ }^{7 a}$ using arrays of four/hydrogen bonding donors-acceptors within single aromatic structures. ${ }^{7}$ Functional groups such as amines, amides, ureas and thioureas, ${ }^{8-12}$ have all been explored as hydrogen bonding donors in this manner. In the past, we have investigated their use in the development of charge neutral receptors for anions. ${ }^{13,14}$ As part of this work, we developed

School of Chemistry, Trinity College Dublin and Trinity Biomedical Science Institute (TBSI), University of Dublin, Dublin 2, Ireland. E-mail: gunnlaut@tcd.ie; Fax: +3531671 2826; Tel: +35318963459

$\dagger$ Electronic supplementary information (ESI) available. CCDC 906513-906518. For crystallographic data in CIF or other electronic format see DOI: 10.1039/ c2ce $26718 \mathrm{~g}$ thiosemicarbazide and semicarbazide based 1,8-naphthlimide structures $^{5 c}$ and showed that these were excellent luminescent and colorimetric sensors for anions in buffered aqueous or organic solutions. ${ }^{15}$ Of these structures, the thiosemicarbazides also gave rise to highly ordered honeycomb solid state structures, formed through hydrogen bonding interactions and weak $\mathrm{F} \cdots \mathrm{F}$ bonds, that were porous, with channels filled with disordered counter ions and solvent molecules. With the view of extending our investigation into the use of such charge neutral hydrogen bonding motifs in anion recognition, sensing and as potential novel building blocks for the generation of networks and polymers, we have designed various families of amido-thiourea ${ }^{16}$ and thiosemicarbazide based structures. Herein, we present the results from the structural investigations of the thiosemicarbazide based structures 1-5, Scheme 1. These are formed by condensing 2-hydrazinopyridine with various isothiocyanates, giving rise to pyridine structures that have the potential to generate ordered hydrogen bonded supramolecular structures; but to<smiles>NNC(=S)NNc1ccccn1</smiles>

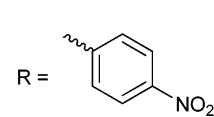

(1)

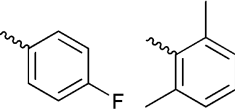

(2)

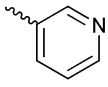

(4)

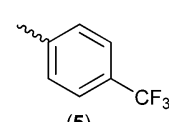

(5)
Scheme 1 Synthesis of compounds 1-5 used in the current study. 


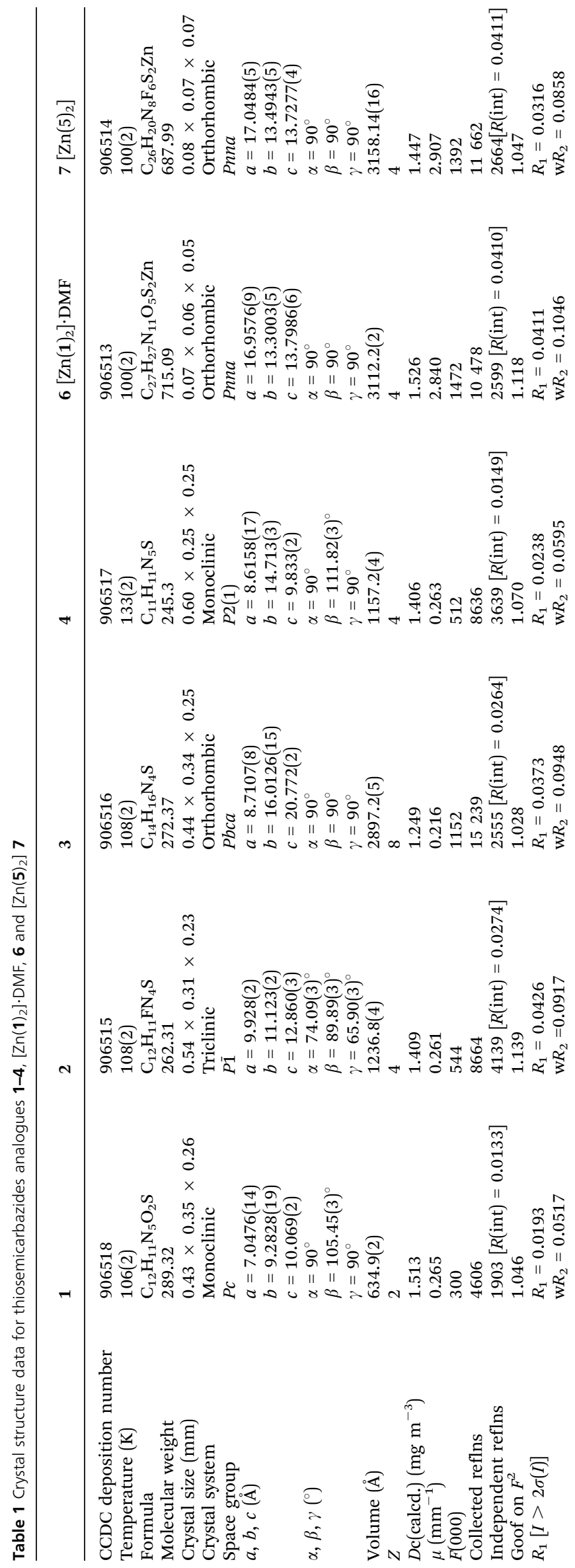




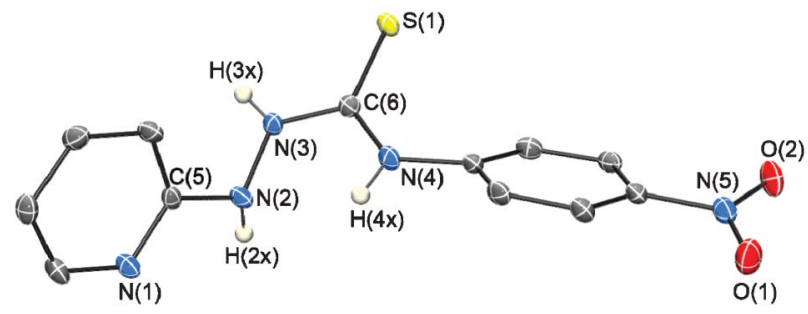

Fig. 1 Perspective view of $\mathbf{1}$. Hydrogen atom and other $\mathrm{NH}$ protons are omitted for clarity. Thermal ellipsoids shown at 50\% probability level.

our surprise, their use in crystal engineering and supramolecular chemistry in general, has received limited attention to date. ${ }^{17}$ Thiosemicarbazides have been used to generate coordination networks using transition metal ions in the past, ${ }^{18-22}$ most notably by Burrow et al. ${ }^{18-20}$ Given that 1-5 all possess one or more pyridine ligands, we extended our investigation into studying the complexation of 1-5 with transition metal ions; with the view of capitalising on the dual functionality of these structures. ${ }^{23}$ In a similar manner pyridyl thiourea structures have also been developed and their hydrogen bonding ability studied in solution and the solid state. $^{24-26}$ Hence, we also report herein, the structural characterisation of two such $\mathrm{Zn}$ (II) complexes, where the combination of metal coordination and hydrogen bonding results in extensive supramolecular networks, possessing porous channels.

\section{Results and discussion}

\section{Synthesis of 1-5}

Thiosemicarbazides 1-5 were synthesised by reacting equimolar ratios of 2-hydrazino-pyridine and substituted isothiocyanates; 4-nitrophenyl (1), 4-fluorophenyl (2), 2,6dimethylphenyl (3), 3-pyridyl (4) and 4-trifluoromethyl-phenyl (5), in acetonitrile under microwave irradiation (Scheme 1). 1 was isolated as a yellow powder while 2-5 were colourless powders. All compounds were fully characterised using standard analytical techniques (see experimental section). In addition, X-ray quality single crystals were obtained of 1-4 and the low temperature (106(2)-133(2) K) X-ray structures determined. Unfortunately despite many attempts utilising different solvents, solvent mixtures and crystallisation methods, X-ray quality crystals of $\mathbf{5}$ were not obtained; but its structural connectivity was later determined as part of a $\mathrm{Zn}$ (II) complex (7).

\section{Structural Analysis of 1-4}

Single crystals of 1-4 were grown by the slow evaporation of acetonitrile at $6-12{ }^{\circ} \mathrm{C}$ and resulted in large block like crystals of 1 (red), 2 (colourless), and 3 (colourless) and large yellow plates of 4 (Table 1). Compound 1 crystallised in the chiral monoclinic space group $P C$ (Fig. 1) and contained one molecule in the asymmetric unit; compound 2 crystallised in the triclinic space group $P \overline{1}$ and contained two molecules in the asymmetric unit; compound 3 crystallised in the chiral orthorhombic space group $P b c a$ with one molecule in the asymmetric unit; and compound $\mathbf{4}$ crystallised in the chiral monoclinic space group $P 2_{1}$ and contained two molecules in the asymmetric unit. The structures were all crystallised under the same conditions, contained no interstitial solvent molecules, a feature that makes structural comparisons much more straightforward.

The thiourea motif of these thiosemicarbazides, adopts in all four structures the anti-conformation a common occurrence in thiourea systems. All $\mathrm{C}=\mathrm{S}$ bond distances are consistent with those expected for thio urea moieties [1.681(17) $\AA$-1.695(2) $\AA$ ] as are the bond lengths and angles of all other functional groups. Another common feature of these systems is the twisting out of plane of the pyridyl group i.e., the thiosemicarbazide $\mathrm{C}(5)-\mathrm{N}(2)-\mathrm{N}(3)-\mathrm{C}(6)$ dihedral angle in each compound is $c a .100^{\circ}$ (Table 2 ).

Analysis of the mean plane angles formed between the thiourea portion of the thiosemicarbazide (N3, C6, N4, and S1) and the substituted phenyl ring reveals that the parasubstituted systems of 1 and 2 are more in plane $\left(43.20(7)^{\circ}\right.$ and $48.31(8)^{\circ}$ respectively) than the di-ortho substituted pyridyl systems 3 and pyridyl substituted $4\left(83.53(5)^{\circ}\right.$ and $80.57(7)^{\circ}$ respectively).

Analysis of the hydrogen bonding interactions involving the relatively acidic thiosemicarbazide protons were undertaken in order to ascertain what effect, if any, the differing substitution patterns had on the packing of the molecules. Three distinct intermolecular hydrogen bonding interactions were observed in 1, involving all of the $\mathrm{N}-\mathrm{H}$ protons (Fig. 2) of the thiosemicarbazide. The molecules form a staggered chain via interactions between $\mathrm{H}(3 \mathrm{X})$ and the pyridyl nitrogen atom, $\mathrm{N}(1)$ on an adjacent molecule $\left[\left(\mathrm{N}(3) \cdots \mathrm{N}(1)^{\prime}=2.993(2) \AA\right.\right.$ and $\left.\angle\left(\mathrm{N}(3)-\mathrm{H}(3 \mathrm{X}) \cdots \mathrm{N}(1)^{\prime}\right)=173.8^{\circ}\right]$ (Fig. 2 and Table 3) and between the sulphur atom, $\mathrm{S}(1)$, and proton of $\mathrm{N}(2)$, $\left[\left(\mathrm{N}(2) \cdots \mathrm{S}(1)^{\prime}=3.421(2) \AA\right.\right.$ and $\left.\angle\left(\mathrm{N}(2)-\mathrm{H}(2 \mathrm{X}) \cdots \mathrm{S}(1)^{\prime}\right)=172.8^{\circ}\right]$ (Fig. 2 and Table 3$)$. The third interaction involves $\mathrm{H}(4 \mathrm{X})$ and

Table 2 Selected bond length and bond angles of 1-4

\begin{tabular}{|c|c|c|c|}
\hline & Bond length of $\mathrm{C}=\mathrm{S}(\AA)$ & Mean plane angle $\left(^{\circ}\right)$ & Dihedral angle $\left({ }^{\circ}\right) \mathrm{C}(5)-\mathrm{N}(2)-\mathrm{N}(3)-\mathrm{C}(6)$ \\
\hline 1 & $1.681(17)$ & $43.20(7)$ & $124.9(2)$ \\
\hline $2^{a}$ & $1.695(2)$ and $1.695(2)$ & $48.31(8)$ and $42.82(9)$ & $106.6(2)$ \\
\hline 3 & $1.6842(17)$ & $83.53(5)$ & $119.0(2)$ \\
\hline $4^{a}$ & $1.693(2)$ and $1.683(2)$ & $80.27(7)$ and $82.57(7)$ & $101.0(2)$ \\
\hline
\end{tabular}




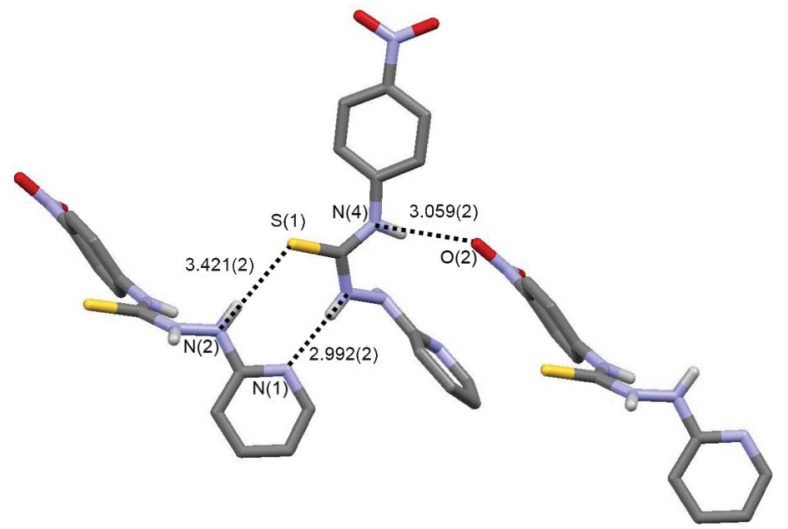

Fig. 2 View of H-bonding in thiourea 1. (N(3) $\cdots N(1),(N(2) \cdots S(1), N(4) \cdots O(2)$ interactions are shown in black dotted bonds.

the nitro oxygen atom, $\mathrm{O}(2)$, on a symmetry generated adjacent molecule, linking together the chains to form a network with $\left[\mathrm{N}(4) \cdots \mathrm{O}(2)=3.059(2)^{\prime} \AA\right.$ and $\left.\angle\left(\mathrm{N}(4)-\mathrm{H}(4 \mathrm{X}) \cdots \mathrm{O}(2)^{\prime}\right)=151.3^{\circ}\right]$, Fig. 2. These three hydrogen bonding interactions between neighbouring urea molecules generate the supramolecular 3D network arrangement as depicted in Fig. 3.

The crystal structure of the $p$-fluoro substituted derivative 2 is shown in Fig. 4. In 2, two crystallographically independent molecules dimerise through complementary hydrogen bonding interactions between the thiosemicarbazide protons $\mathrm{H}(4 \mathrm{X})$ and $\mathrm{H}(24 \mathrm{X})$ and the pyridyl nitrogen atoms $\mathrm{N}(1)$ and $\mathrm{N}(21)$; $\left[\mathrm{N}(4) \cdots \mathrm{N}(21)^{\prime}=2.861(3) \AA\right.$ and $\angle\left(\mathrm{N}(4)-\mathrm{H}(4 \mathrm{X}) \cdots \mathrm{N}(21)^{\prime}\right)=145(3)^{\circ}$; $\mathrm{N}(24) \cdots \mathrm{N}(1)^{\prime}=2.892(3) \AA$ and $\angle\left(\mathrm{N}(24)-\mathrm{H}(24 \mathrm{X}) \cdots \mathrm{N}(1)^{\prime}\right)=$ $\left.149(2)^{\circ}\right]$. These dimers are then extended along the crystallographic $a$ axis through further complementary hydrogen

Table 3 Hydrogen bonding parameters for $\mathbf{1 - 4 ^ { a }}$

\begin{tabular}{|c|c|c|c|c|}
\hline & $\mathrm{D}-\mathrm{H} \cdots \mathrm{A}$ & $d(\mathrm{H} \cdots \mathrm{A})$ & $d(\mathrm{D} \cdots \mathrm{A})$ & $\angle(\mathrm{DHA})$ \\
\hline \multirow[t]{3}{*}{1} & $\mathrm{~N}(2)-\mathrm{H}(2 \mathrm{X}) \cdots \mathrm{S}(1)^{\mathrm{a}}$ & 2.53 & $3.421(2)$ & 172.8 \\
\hline & $\mathrm{N}(3)-\mathrm{H}(3 \mathrm{X}) \cdots \mathrm{N}(1)^{\mathrm{b}}$ & 2.19 & $2.992(2)$ & 173.8 \\
\hline & $\mathrm{N}(4)-\mathrm{H}(4 \mathrm{X}) \cdots \mathrm{O}(2)^{\mathrm{c}}$ & 2.26 & $3.059(2)$ & 151.3 \\
\hline \multirow[t]{5}{*}{2} & $\mathrm{~N}(3)-\mathrm{H}(3 \mathrm{X}) \cdots \mathrm{S}(21)$ & 2.47 & $3.329(2)$ & 165 \\
\hline & $\mathrm{N}(4)-\mathrm{H}(4 \mathrm{X}) \cdots \mathrm{N}(21)^{\mathrm{d}}$ & 4111 & $2.861(3)$ & 145 \\
\hline & $N(22)-H(22 X) \cdots S(1)^{e}$ & 2.51 & $3.303(2)$ & 146 \\
\hline & $\mathrm{N}(23)-\mathrm{H}(23 \mathrm{X}) \cdot \cdots \mathrm{S}(1)$ & 2.56 & $3.414(2)$ & 170 \\
\hline & $\mathrm{N}(24)-\mathrm{H}(24 \mathrm{X}) \cdots \mathrm{N}(1)^{\mathrm{f}}$ & 2.13 & $2.892(3)$ & 149 \\
\hline \multirow[t]{2}{*}{3} & $\mathrm{~N}(2)-\mathrm{H}(2 \mathrm{X}) \cdots \mathrm{S}(1)^{\mathrm{g}}$ & 2.44 & $3.301(14)$ & 161.0 \\
\hline & $\mathrm{N}(3)-\mathrm{H}(3 \mathrm{X}) \cdots \mathrm{N}(1)^{\mathrm{h}}$ & 2.08 & $2.972(19)$ & 172.6 \\
\hline \multirow[t]{6}{*}{4} & $\mathrm{~N}(2)-\mathrm{H}(2 \mathrm{X}) \cdots \mathrm{N}(5)^{\mathrm{i}}$ & 2.10 & $2.955(3)$ & 172 \\
\hline & $\mathrm{N}(3)-\mathrm{H}(3 \mathrm{X}) \cdots \mathrm{S}(21)^{\mathrm{j}}$ & 2.34 & $3.274(2)$ & 166 \\
\hline & $\mathrm{N}(4)-\mathrm{H}(4 \mathrm{X}) \cdots \mathrm{N}(21)^{\mathrm{i}}$ & 2.17 & $2.972(2)$ & 149 \\
\hline & $\mathrm{N}(22)-\mathrm{H}(22 \mathrm{X}) \cdots \mathrm{N}(25)^{\mathrm{k}}$ & 1.99 & $2.937(3)$ & 170 \\
\hline & $\mathrm{N}(23)-\mathrm{H}(23 \mathrm{X}) \cdots \mathrm{S}(1)^{1}$ & 2.52 & $3.320(2)$ & 157 \\
\hline & $\mathrm{N}(24)-\mathrm{H}(24 \mathrm{X}) \cdots \mathrm{N}(1)^{\mathrm{m}}$ & 2.17 & $2.989(2)$ & 158 \\
\hline
\end{tabular}

${ }^{a}$ Symmetry equivalents used: ${ }^{\mathrm{a}} x,-y+1, z+1 / 2 ;{ }^{\mathrm{b}} x,-y+1, z-1 /$ $2 ;{ }^{\mathrm{c}} x+1,-y, z+1 / 2 ;{ }^{\mathrm{d}} x-1, y, z ;{ }^{\mathrm{e}}-x+1,-y+1,-z ;{ }^{\mathrm{f}} x+1, y, z ;{ }^{\mathrm{g}} x$ $-1 / 2, y,-z+1 / 2 ;{ }^{\mathrm{h}} x+1 / 2, y,-z+1 / 2 ;{ }^{\mathrm{i}}-x+1, y+1 / 2,-z+2 ;{ }^{\mathrm{j}}-x$ $+1, y+1 / 2,-z+1 ;{ }^{\mathrm{k}}-x, y-1 / 2,-z+1 ;{ }^{1}-x+1, y-1 / 2,-z+1$; $\mathrm{m}_{-x}+1, y-1 / 2,-z+2$.

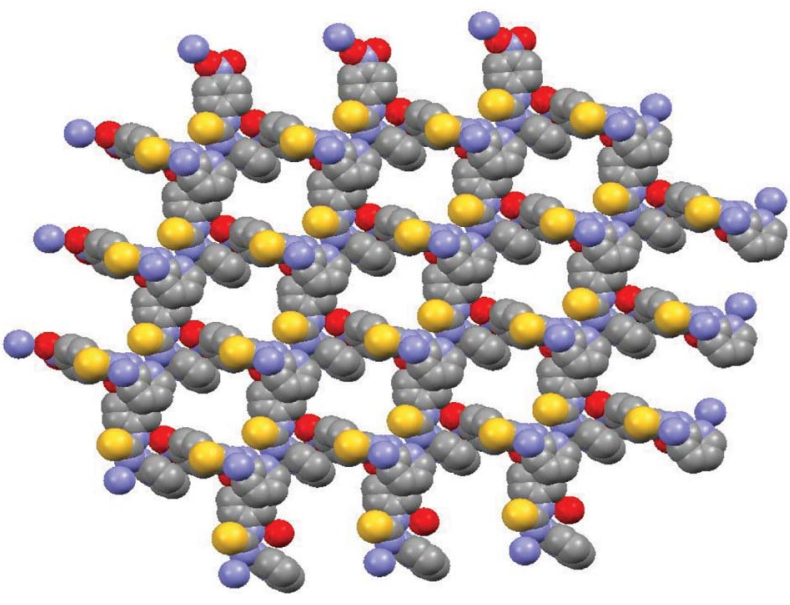

Fig. $\mathbf{3}$ Network arrangement of $\mathbf{1}$ formed through intermolecular hydrogen bonding interactions.

bonding interactions between thiosemicarbazide protons $\mathrm{H}(3 \mathrm{X})$ and $\mathrm{H}(23 \mathrm{X})$ and the sulphur atoms $\mathrm{S}(1)$ and $\mathrm{S}(21)$ on adjacent molecules $[\mathrm{N}(3) \cdots \mathrm{S}(21)=3.329(2) \AA$ and $\angle(\mathrm{N}(3)-$ $\mathrm{H}(3 \mathrm{X}) \cdots \mathrm{S}(21))=165(2)^{\circ} ; \mathrm{N}(23) \cdots \mathrm{S}(1)=3.414(2) \AA$ and $\angle(\mathrm{N}(23)-$ $\left.\mathrm{H}(23 \mathrm{X}) \cdots \mathrm{S}(1)=170(2)^{\circ}\right]$. These hydrogen bonding interactions result in the formation of a $1 \mathrm{D}$ polymeric chain, where strands of this polymer are linked though hydrogen bonding interactions between the amino proton $\mathrm{H}(22 \mathrm{X})$ and sulphur atom $\mathrm{S}(1) ;[\mathrm{N}(22) \cdots \mathrm{S}(1)=3.303(2) \AA$ and $\angle(\mathrm{N}(22)-\mathrm{H}(22 \mathrm{X}) \cdots \mathrm{S}(1))=$ $\left.146(2)^{\circ}\right]$ These interactions lead to the polymeric network shown in Fig. 5, in contrast to the network arrangement of $\mathbf{1 .}$ Unlike the structure of $\mathbf{1}$, the H-bonding does not involve the phenyl substituent, i.e. the fluorine atoms is not involved in H-bonding.

The molecular structure of the dimethylphenyl analogue 3 crystallises in the orthorhombic space group $\mathrm{Pbca}$ and is shown in Fig. 6, where it can be seen that 3 exhibits two distinct intermolecular hydrogen bonding interactions. The strongest between $\mathrm{N}(3)$ and the pyridyl nitrogen atoms on a neighbouring molecule $(\mathrm{N}(1))\left[\mathrm{N}(3) \cdots \mathrm{N}(1)^{\prime}=2.973(2) \AA\right.$ and $\left.\angle\left(\mathrm{N}(3)-\mathrm{H}(3 \mathrm{X}) \cdots \mathrm{N}(1)^{\prime}\right)=172(3)^{\circ}\right]$ and a weaker interaction between hydrazino amine $\mathrm{N}(2)$ part of the thiosemicarbazide and the sulphur atom $\left(\mathrm{S}(1)^{\prime}\right)$ on a neighbouring molecule $\left[\mathrm{N}(2) \cdots \mathrm{S}(1)^{\prime}=3.301(2) \AA\right.$ and $\left.\angle\left(\mathrm{N}(2)-\mathrm{H}(2 \mathrm{X}){ }^{\cdots} \mathrm{S}(1)^{\prime}\right)=161(3)^{\circ}\right]$. The result of these hydrogen bonding interactions is a one dimensional polymeric chain, Fig. 7.

The inclusion of a second pyridyl functionality into the thiosemicarbazide family was also investigated as it was thought that the extra hydrogen bond acceptor would alter the hydrogen bonding and therefore the packing interactions. The crystal structure of $\mathbf{4}$ with pyridyl functionality is shown in Fig. 8. The presence of the extra pyridyl ring in 4 contributes to additional hydrogen bonding unlike 1-3 with phenyl based substituents, and 4 exhibits six distinct intermolecular hydrogen bonding interactions, Fig. 9.

The molecules form 1D hydrogen bonded chains through four hydrogen bonds in a similar manner to the H-bonding pattern in 2. Dimers of molecules are formed through 


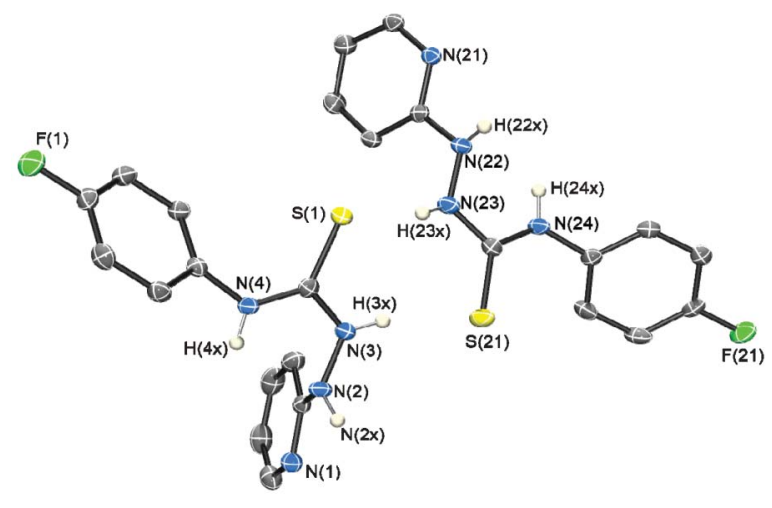

Fig. 4 Perspective view of $\mathbf{2}$. Hydrogen atoms other than $\mathrm{NH}$ protons omitted for clarity. Thermal ellipsoids shown at 50\% probability level.

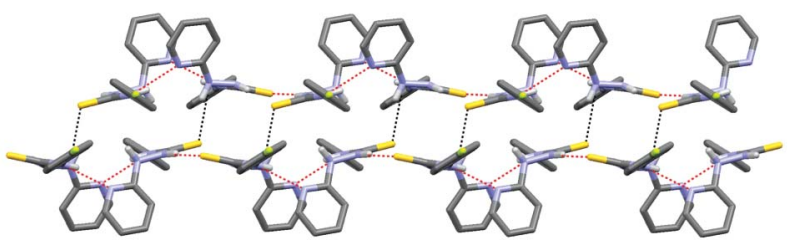

Fig. 5 Hydrogen bonded polymeric chain of 2. $N(4) \cdots N(21) ; N(24) \cdots N(1)$ are shown in red dotted bonds and $\mathrm{N}(3) \cdots \mathrm{S}(21)$ and $\mathrm{N}(22) \cdots \mathrm{S}(1)$ black dotted bonds.

interactions between the sulphur atoms $\mathrm{S}(21)$ and $\mathrm{S}(1)$ and $\mathrm{NH}$ protons of $\mathrm{N}(3)$ and $\mathrm{N}(23)$ on an adjacent thiosemicarbazide molecule $\left[\mathrm{N}(3) \cdots \mathrm{S}(21)^{\prime}=3.274(2) \AA\right.$ and $\angle\left(\mathrm{N}(3)-\mathrm{H}(3 \mathrm{X}) \cdots \mathrm{S}(21)^{\prime}\right)$ $=166^{\circ} ; \mathrm{N}(23) \cdots \mathrm{S}(1)^{\prime}=3.320(2) \AA, \angle\left(\mathrm{N}(23)-\mathrm{H}(23 \mathrm{X}) \cdots \mathrm{S}(1)^{\prime}\right)=$ $\left.157^{\circ}\right]$ respectively. These dimers are then linked into the aforementioned 1D chain though two more hydrogen bonding interactions between the $\mathrm{NH}$ protons of $\mathrm{N}(4)$ and $\mathrm{N}(24)$ and the 2-pyridyl nitrogen atoms of $\mathrm{N}(1)$ and $\mathrm{N}(21)$ on adjacent molecules $\left[\mathrm{N}(4) \cdots \mathrm{N}(21)^{\prime}=2.972(2) \quad \AA\right.$ and $\angle(\mathrm{N}(4)-$ $\left.\mathrm{H}(4 \mathrm{X}) \cdots \mathrm{N}(21)^{\prime}\right)=149^{\circ} ; \mathrm{N}(24) \cdots \mathrm{N}(1)^{\prime}=2.989(2) \AA, \angle(\mathrm{N}(24)-$ $\left.\left.\mathrm{H}(24 \mathrm{X}) \cdots \mathrm{N}(1)^{\prime}\right)=158^{\circ}\right]$ (Fig. 9). These $1 \mathrm{D}$ chains are then cross linked to other symmetry generated chains via the 3-pyridyl nitrogen atoms and the proton on an adjacent thiosemicarbazide molecule $\left[\mathrm{N}(2) \cdots \mathrm{N}(5)^{\prime}=2.955(3) \AA\right.$ and $\angle(\mathrm{N}(2)-$ $\left.\mathrm{H}(2 \mathrm{X})^{\cdots} \mathrm{N}(5)^{\prime}\right)=172^{\circ} ; \mathrm{N}(22)^{\cdots} \mathrm{N}(25)^{\prime}=2.937(3) \AA, \angle(\mathrm{N}(22)-$

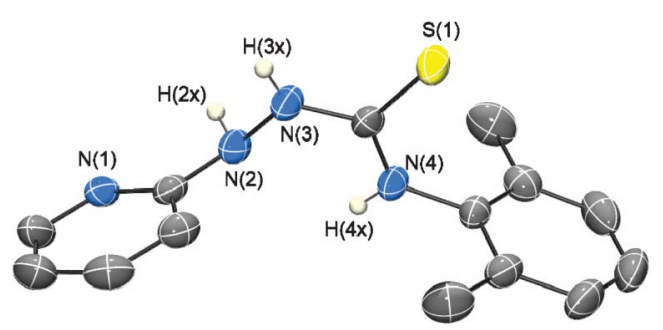

Fig. 6 Perspective view of 3. Hydrogen atoms other than NH protons omitted for clarity. Thermal ellipsoids shown at 50\% probability level.

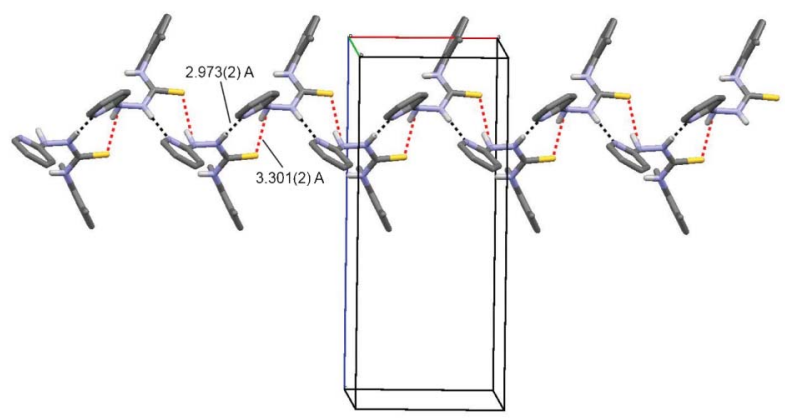

Fig. 7 Hydrogen bonded polymeric chain of $\mathbf{3}$ viewed down the $c$ axis. $N(3) \cdots N(1), N(2) \cdots S(1)$, interactions are shown in black and red bonds respectively.

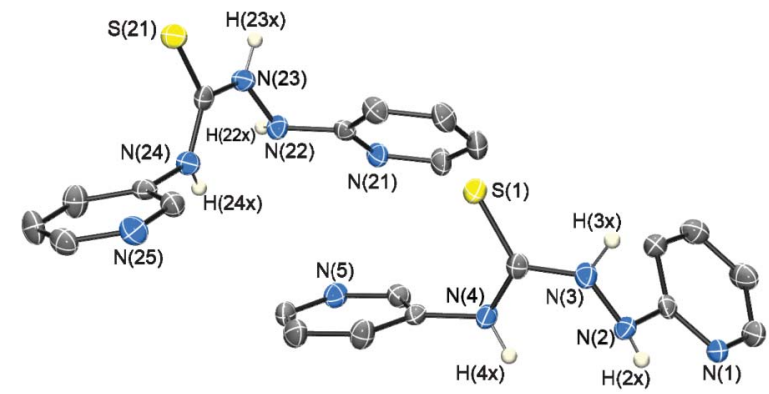

Fig. 8 Perspective view of $\mathbf{4}$. Hydrogen atom and other NH protons are omitted for clarity. Thermal ellipsoids shown at 50\% probability level.

$\left.\left.\mathrm{H}(22 \mathrm{X}) \cdots \mathrm{N}(25)^{\prime}\right)=170^{\circ}\right]$. Detailed hydrogen bonding parameters are given in Table 3.

\section{Complexation studies with Zn(II)}

Having investigated the hydrogen bonding properties of 1-4, we next set out to investigate their potential use in metallosupramolecular chemistry. Complexation reactions were carried out between all five ligands and $\mathrm{Zn}\left(\mathrm{NO}_{3}\right)_{2}$ by stirring at reflux in acetonitrile. Despite many attempts to obtain single crystals for all five ligand systems, X-ray quality crystals were only obtained from reactions using ligands $\mathbf{1}$ and $\mathbf{5}$ by the slow evaporation of DMF and acetonitrile respectively. Structural

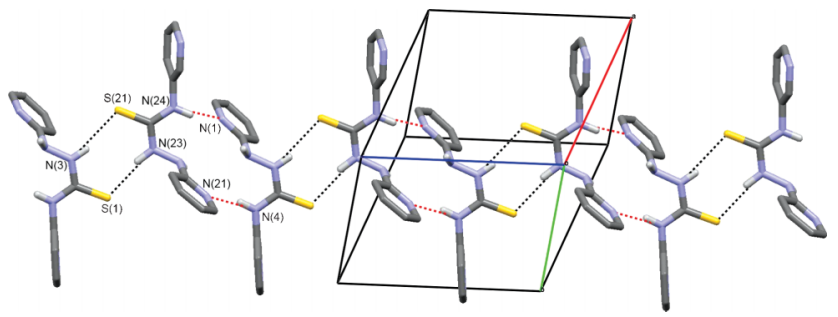

Fig. 9 Hydrogen bonding interactions in thiourea 4, $N(1)-N(24)$ and $N(21)-N(4)$; $\mathrm{N}(3) \cdots \mathrm{S}(21)$ and $\mathrm{N}(23) \cdots \mathrm{S}(1)$ interactions are shown in black and red dotted bonds respectively. 


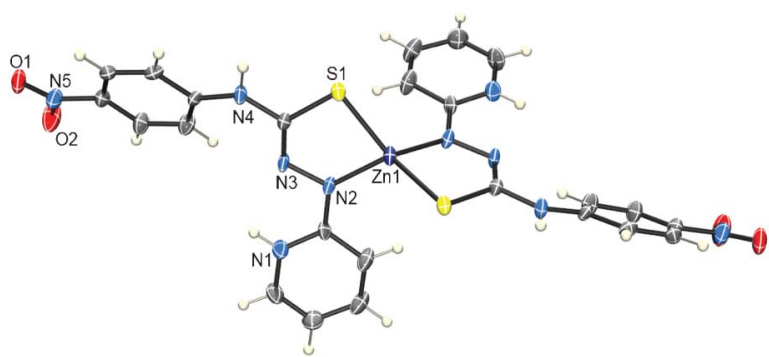

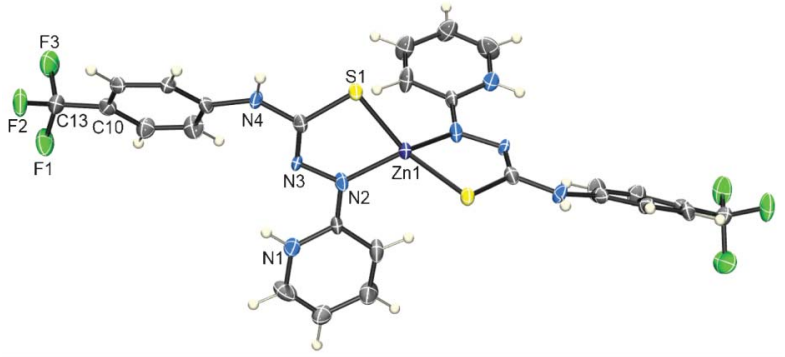

Fig. 10 View of crystal structures of $\left[\mathrm{Zn}(\mathbf{1})_{2}\right] \cdot \mathrm{DMF}$ (top) and $\left[\mathrm{Zn}(\mathbf{5})_{2}\right]$ (bottom). Thermal ellipsoids shown at $50 \%$ probability.

analysis revealed neutral, mononuclear complexes of formulae $\left[\mathrm{Zn}(1)_{2}\right] \cdot \operatorname{DMF}(\mathbf{6})$ and $\left[\mathrm{Zn}(5)_{2}\right](7)$. The crystal structures of both $\mathrm{Zn}$ (II) complexes are shown in Fig. 10.

Both complexes crystallised in the orthorhombic space group Pnna and contain half of the complex in the asymmetric unit with the $\mathrm{Zn}(\mathrm{II})$ located on a two-fold rotation axis. Within the asymmetric unit the $\mathrm{Zn}$ (II) is coordinated by one, deprotonated nitrogen atom $\mathrm{N}(2)$, and the sulphur atom $\mathrm{S}(1)$ to give a five membered chelate ring. The two-fold axis generates the other half of the complexes giving the $\mathrm{Zn}(\mathrm{II})$ a tetrahedral geometry and an overall $\mathrm{N}_{2} \mathrm{~S}_{2}$ coordination environment. Bond lengths and angles are consistent with those expected for tetrahedral $\mathrm{Zn}$ (II) complexes of this coordination environment. ${ }^{27,28}$

In both 6 and 7 the pyridine nitrogen atom $N(1)$ is protonated, rather than the thiourea nitrogen atom $\mathrm{N}(3)$, a feature likely arising from the highly acidic thiourea nitrogen atom involved in the chelate ring. In a similar fashion to the structures of ligands 1-4, the Zn(II) complexes 6 and $\mathbf{7}$ both exhibit inter molecular hydrogen bonding that results in the formation of extended coordination polymeric structures. In contrast to the ligand packing interactions, both 6 and 7 pack in such a way that they form channels within the structure (Fig. 11). In the case of complex 6, the disordered DMF solvent molecule resides within the cavity of these channels. In contrast, no solvent molecules were found within the channels of 7. Thermal stability of the zinc complex 6 was studied by thermal gravimetric analysis (TGA). The thermogram of $\mathbf{6}$ showed a gradual weight loss of $\sim 10 \%\left(20-220{ }^{\circ} \mathrm{C}\right)^{30}$ which corresponds to the loss of one $N, N$-dimethylformamide (DMF) from the pores of the crystalline 6, (Fig. S1 and S2, ESI $\dagger$ ).

Each of the complexes display the same hydrogen bonding pattern in that the protonated pyridine nitrogen atom N(1) hydrogen bonds to the phenyl substituent on a neighbouring
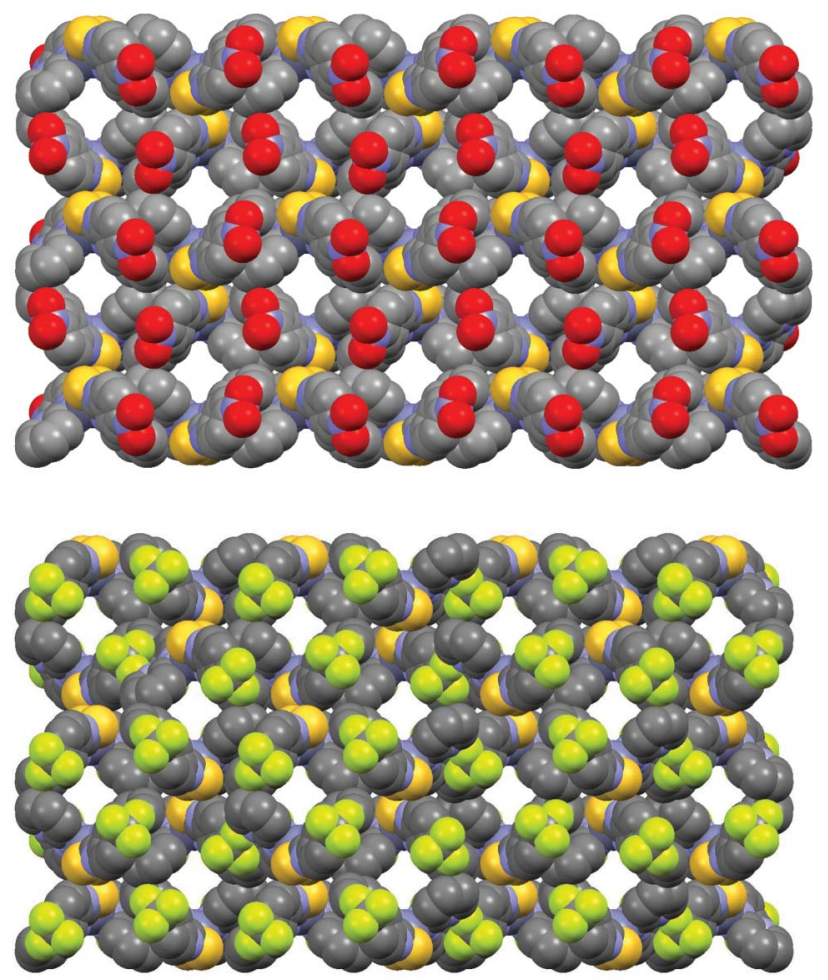

Fig. 11 Spacefill representations of the packing of $\mathbf{6}$ (top) and $\mathbf{7}$ (bottom) showing the solvent accessible channels.

molecule $\left(\mathrm{NO}_{2}\right.$ or $\mathrm{CF}_{3}$ for 6 and 7 respectively) giving rise to an extended 1D chain [for $6 \mathrm{~N}(1) \cdots \mathrm{O}(1)^{\prime}=2.928(5) \AA$ and $\angle(\mathrm{N}(1)-$ $\left.\mathrm{H}(1 \mathrm{X}) \cdots \mathrm{O}(1)^{\prime}\right)=137^{\circ}$; for $7 \mathrm{~N}(1)^{\cdots} \cdots \mathrm{F}(2)^{\prime}=3.046(7) \AA$ and $\angle(\mathrm{N}(1)-$ $\left.\mathrm{H}(1 \mathrm{X}) \cdots \mathrm{F}(2)^{\prime}\right)=138^{\circ}$ ] (Fig. 12 and 13). These chains are then linked to neighbouring chains though hydrogen bonds involving the coordinated sulphur atom $\mathrm{S}(1)$ and the $\mathrm{NH}$ thiosemicarbazide proton of $\mathrm{N}(4)$ on a neighbouring molecule [for $6 \mathrm{~N}(4) \cdots \mathrm{S}(1)^{\prime}=3.417(4) \AA$ and $\angle\left(\mathrm{N}(4)-\mathrm{H}(4 \mathrm{X}) \cdots \mathrm{S}(1)^{\prime}\right)=165^{\circ}$;

a)

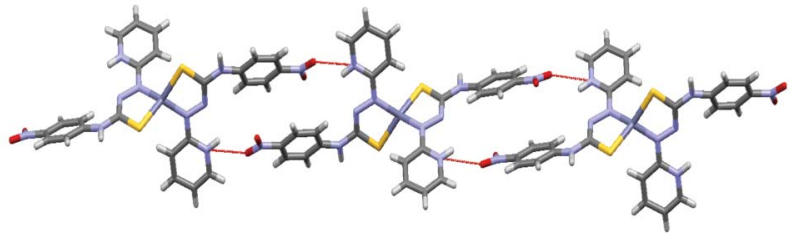

b)

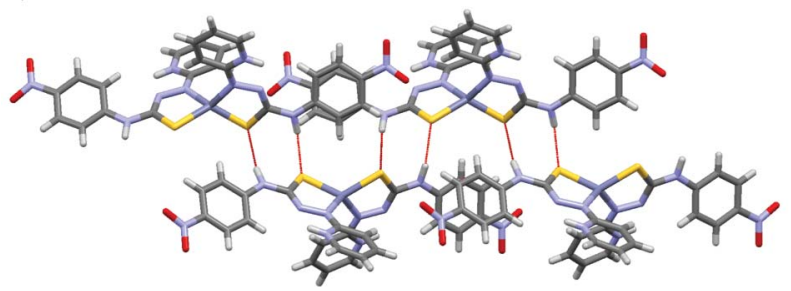

Fig. 12 View of intermolecular hydrogen bonding interactions in $\left[\mathrm{Zn}(\mathbf{1})_{2}\right] \cdot \mathrm{DMF}$ (6). a) $\mathrm{N}-\mathrm{H} \cdots \mathrm{O}$ interactions in 6. b) $\mathrm{N}-\mathrm{H} \cdots \mathrm{S}$ interactions in $\mathbf{6}$ 
a)

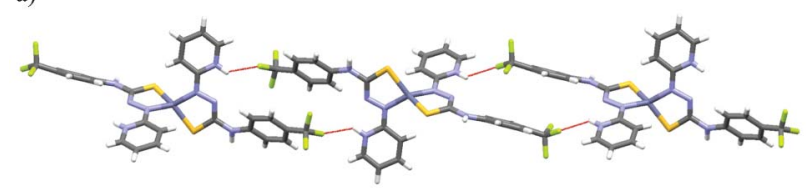

b)

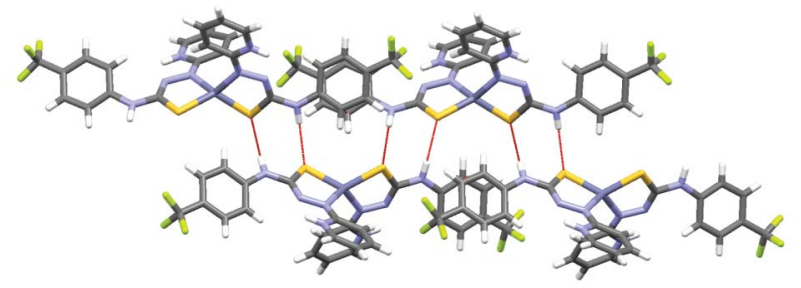

Fig. 13 View of intermolecular hydrogen bonding interactions in $\left[\mathrm{Zn}(\mathbf{5})_{2}\right](\mathbf{7})$. a) $\mathrm{N}-\mathrm{H} \cdots \mathrm{F}$ interactions in $\mathbf{7}$. b) $\mathrm{N}-\mathrm{H} \cdots \mathrm{S}$ interactions in $\mathbf{7}$.

for $7 \mathrm{~N}(4) \cdots \mathrm{S}(1)^{\prime}=3.445(6) \AA$ and $\angle\left(\mathrm{N}(4)-\mathrm{H}(4 \mathrm{X}){ }^{\cdots} \mathrm{S}(1)^{\prime}\right)=174^{\circ}$ ]. The result of these intermolecular hydrogen bonding interactions is the formation of the aforementioned channels.

Analysis of the void space of the channels of 6 and 7 was carried out using MERCURY and the voids appear to adopt channels through the crystal lattice where the solvent accessible surface is continuous to a probe radius of 1.21.7 Å for 6 and 1.2-1.5 A for 7 (see Table 4, Fig. 14 a-d). In both 6 and 7 , the voids form interconnected infinite channels that might potentially allow for uptake of small molecules such as $\mathrm{H}_{2}, \mathrm{CH}_{4}$ etc. ${ }^{31}$ The solvent accessible void in the asymmetric unit of $\mathbf{6}$ is occupied by a disordered DMF molecule and the void may not be stable to removal of DMF.

Whilst the void analysis of both 6 and 7 indicates that the crystals might be porous, we are hesitant to describe them as such without further experimental data (solvent uptake and crystal stability under vacuum). ${ }^{31,32}$ Nonetheless these are encouraging results and further investigations into the porosity are on-going. Research is on-going in our group to incorporate new donor-acceptor functional groups into the ligand design and subsequently prepare and study the $d$-metal ion complexes and their host-guest interactions.

Table 4 Calculated values of cavity volumes for solvent accessible surface of $\left[\mathrm{Zn}(\mathbf{1})_{2}\right]$ and $\left[\mathrm{Zn}(\mathbf{5})_{2}\right]$, Fig. 14

\begin{tabular}{lll}
\hline Probe radius $(\AA)$ & $\begin{array}{l}{\left[\mathrm{Zn}(\mathbf{1})_{2}\right]^{a}} \\
\text { Void volume }\left(\AA^{3}\right)\end{array}$ & $\begin{array}{l}{\left[\mathrm{Zn}(\mathbf{5})_{2}\right]} \\
\text { Void volume }\left(\AA^{3}\right)\end{array}$ \\
\hline 1.7 & $23.14(0.7)$ & $3.07(0.1)^{b}$ \\
1.6 & $34.76(1.1)$ & $8.22(0.3)^{b}$ \\
1.5 & $51.67(1.7)$ & $17.37(0.5)$ \\
1.4 & $70.14(2.2)$ & $28.66(0.9)$ \\
1.3 & $91.82(2.9)$ & $44.42(1.4)$ \\
1.2 & $118.80(3.8)$ & $64.13(2.0)$
\end{tabular}

${ }^{a}$ Squeeze command was used to remove the disordered DMF for analysis use only. ${ }^{b}$ Channels are not continuous.

\section{Photo luminescent properties of 7}

Both the zinc complexes 6 and 7 have been investigated for their photoluminescent properties. The spectroscopic studies of Zinc complexes 6 and 7 were carried out in acetonitrile solution $\left(1 \times 10^{-5} \mathrm{M}\right)$. Complex 7 with a $p-\mathrm{CF}_{3}$ group exhibits blue luminescence $\left(\lambda_{\max }=440 \mathrm{~nm}\right)$ when excited at $290 \mathrm{~nm}$, Fig. 15. ${ }^{33}$ Conversely, thiosemicarbazide ligand 5 does not exhibit luminescent properties suggesting that the photoluminescence arises from ligand to metal charge transfer (LMCT). Zinc complex 6 with $p$-nitro group does not exhibit any luminescent property, Fig. S3, ESI. $\dagger$ We are in the process however, of investigating these luminescent properties further.

\section{Conclusions}

In this article, we have presented the synthesis and structural characterisation of thiosemicarbazide based ligands which contain a variety of aromatic substituents (4-nitrophenyl (1), 4-fluorophenyl (2), 2,6-dimethylphenyl (3), 3-pyridyl (4) and 4-trifluoromethyl (5). These ligands are all rich in hydrogen bond donors and acceptors and as such the solid state packing interactions were complex in nature and significantly influenced by the nature of the substituents. The introduction of hydrogen bond acceptors to the substituents allows the compounds to form extended networks whereas 2, which has no additional acceptors (other than the sulphur and thiosemicarbazide/pyridine nitrogen atoms) forms a simple 1D chain. All of the structures 1-4 formed well packed systems with no porous networks; however, the incorporation of $\mathrm{Zn}$ (II) resulted in porous, hydrogen bonded networks. Complexes formed only with ligands $\mathbf{1}$ and $\mathbf{5}$ via coordination to the sulphur atom and the hydrazino nitrogen atom of the thiosemicarbazide functionality to give neutral bis ligand complexes of general formulae, $\left[\mathrm{Zn}(\mathrm{L})_{2}\right]$ ( 6 and 7 ). The large channels formed through extended $\mathrm{H}$-bonding interactions are of sufficient size to include solvent molecules, ${ }^{29}$ and although no solvent was occupying the channels in 7 , a disordered DMF molecule was located in the pores of 6 . These porous $\mathrm{Zn}$ (II) networks represent our first step towards the development of systems that might act as storage compounds, or indeed $\mathrm{Zn}$ (II) based luminescent sensing materials where inclusion of a guest molecule within the pores might modulate the fluorescent/luminescent properties of the $\mathrm{Zn}$ (II) centre.

In summary, we have developed a structurally simple family of hydrogen bonding donors that possess an additional one or two metal coordination sites. We demonstrated that while the thiosemicarbazides 1-4 all gave rise to extensive intermolecular hydrogen bonding interactions, they can also be employed in the formation of $\mathrm{H}$-bonded coordination networks with $\mathrm{Zn}$ (II). We are in the process of further evaluating the application of these and related systems based on the thiosemicarbazide structure for use in supramolecular chemistry and crystal engineering. 


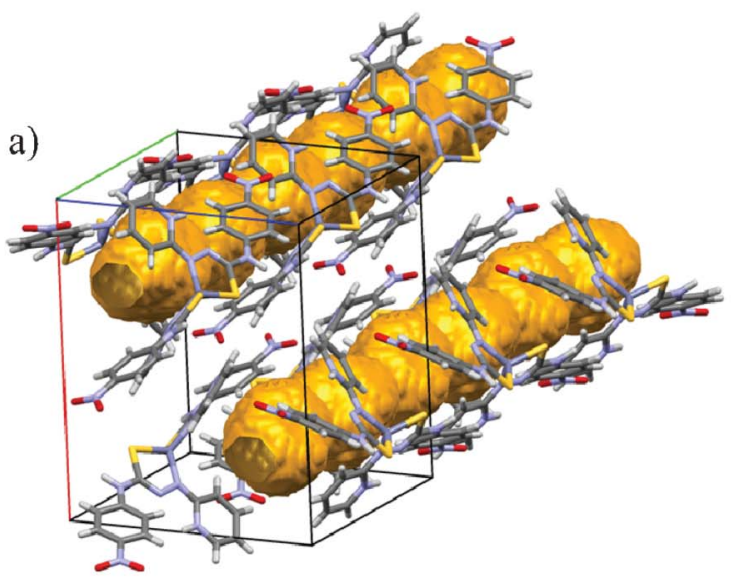

b)
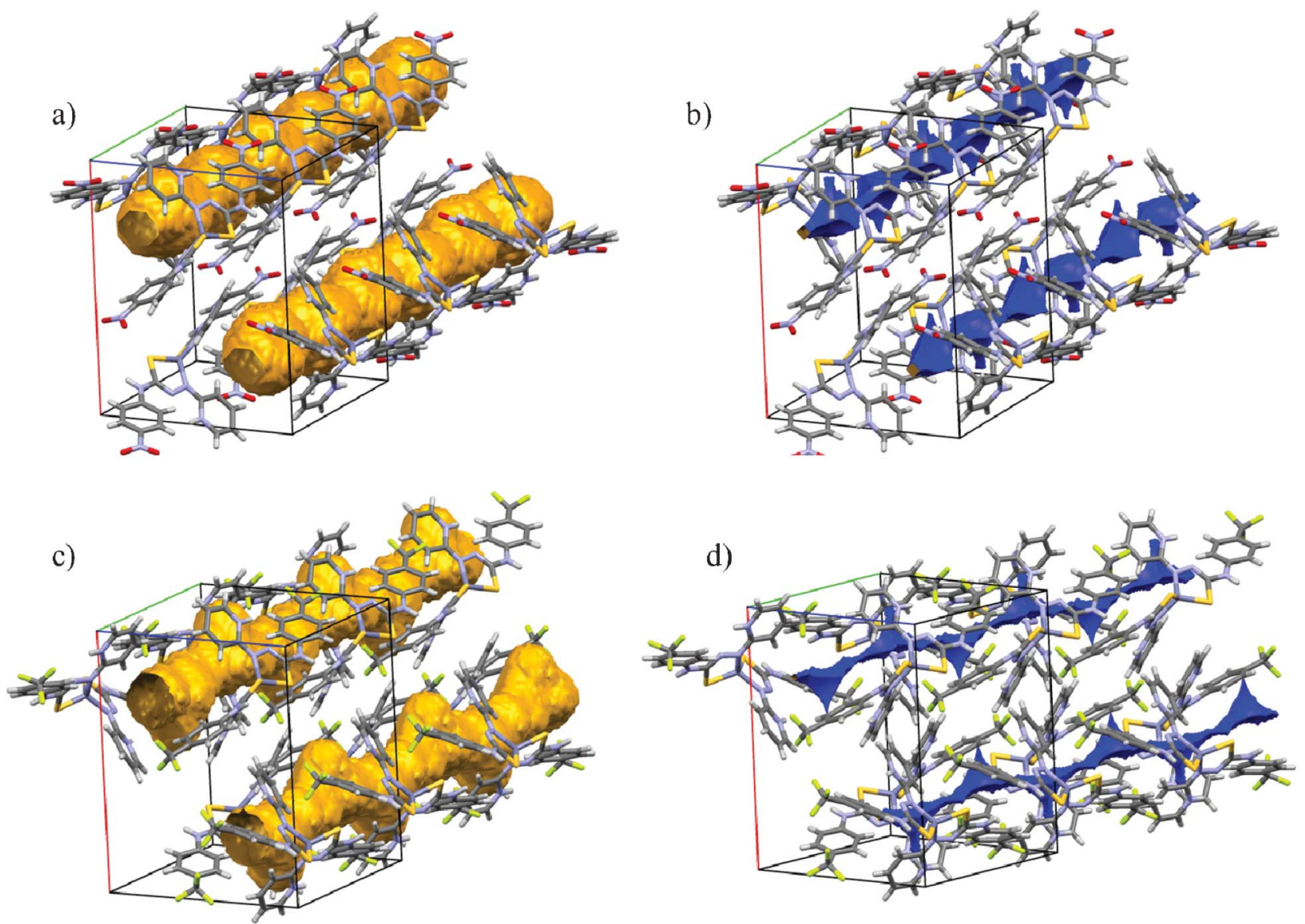

Fig. 14 Void analyses of zinc(II) complexes $\mathbf{6}$ and 7. a) Continuous contact surfaces generated using a probe radius of $1.8 \AA$ An $\mathbf{6}$. b) Continuous solvent accessible voids generated using a probe radius of $1.5 \AA$ in $\mathbf{6}$. c) Continuous contact surfaces generated using a probe radius of $1.5 \AA$ in $\mathbf{7}$. d) Continuous solvent accessible surface generated using a probe radius of $1.5 \AA$. Solvent accessible voids are continuous and can participate in solvent inclusion.

\section{Experimental}

All chemical were purchased from Sigma-Aldrich and Fluka chemical company and used without purification. Synthesis of 1-5 were carried out in 10-20 mL Biotage Microwave Vials in a Biotage Initiator Eight EXP microwave reactor. Column

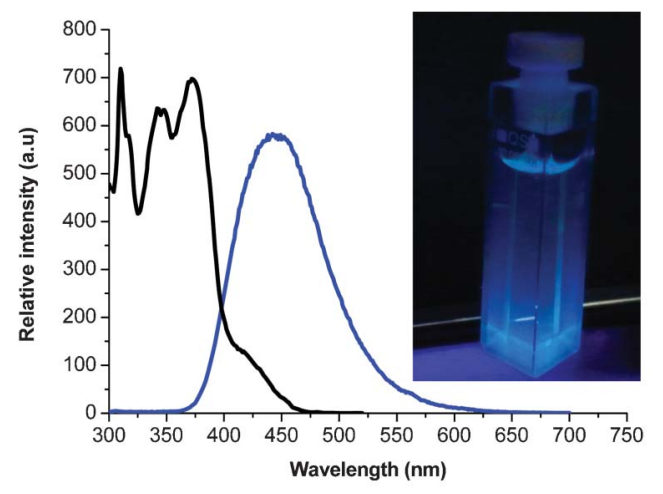

Fig. 15 Excitation and emission spectra of $\left[\mathrm{Zn}(\mathbf{5})_{2}\right], 7$ in $\mathrm{CH}_{3} \mathrm{CN}$; inset image shows luminescent $\left[\mathrm{Zn}(\mathbf{5})_{2}\right], \mathbf{7}$. chromatography was performed using silica gel 60 (230-40 mesh ASTM). Melting points were recorded on an Electro thermal IA9000 digital melting point apparatus. Infra-red spectra were recorded on a Perkin-Elmer spectrum one FT-IR spectrometer equipped with a universal ATR sampling accessory. ${ }^{1} \mathrm{H}$ and ${ }^{13} \mathrm{C}$ NMR spectra were recorded using a Bruker DPX-400 instrument. The samples were dissolved in DMSO- $d_{6}$ and spectra were recorded in a $5 \mathrm{~mm}$ NMR tube. Chemical shifts are reported relative to tetramethylsilane and coupling constants are given in Hertz. The elemental analysis for $\mathrm{C}, \mathrm{H}$ and $\mathrm{N}$ was performed on an Exeter analytical CE-450 Elemental analyzer in University College Dublin. Electrospray mass spectra were recorded on a Mass Lynx NT V 3.4 on a Waters 600 controller. Thermal gravimetric analysis (TGA) was performed on Perkin-Elmer Pyrus 1 TGA equipped with an ultra-micro balance with a sensitivity of 0.1 microgram. The temperature range is from $20-700{ }^{\circ} \mathrm{C}$ with a scan rate $10{ }^{\circ} \mathrm{C}$ $\min ^{-1}$. X-ray data (Table 1) were collected on either a Rigaku Saturn 724 CCD Diffractometer using graphite-monochromated Mo $K \alpha$ radiation $(\lambda=0.71073 \AA)$ or a Bruker Apex 2 Duo using a high intensity $\mathrm{Cu} \alpha \alpha$ radiation source $(\lambda=1.54178 \AA)$. The data sets from the Rigaku Saturn-724 diffractometer were 
collected using Crystalclear-SM 1.4.0 software. Data integration, reduction and correction for absorption and polarisation effects were all performed using the Crystalclear-SM 1.4.0 software. Space group determination, was obtained using Crystalstructure ver.3.8 software. Datasets collected on the Bruker Apex2 Duo were processed using Bruker APEXv2011.8-0 software. The structures were solved by direct methods (SHELXS-97) and refined against all $F^{2}$ data (SHELXL-97). ${ }^{34}$ All $\mathrm{H}$-atoms, except for $\mathrm{N}-\mathrm{H}$ protons, were positioned geometrically and refined using a riding model with $d\left(\mathrm{CH}_{\text {aro }}\right)$ $=0.95 \AA, U_{\text {iso }}=1.2 U_{\text {eq }}(\mathrm{C})$ for aromatic and $0.98 \AA, U_{\text {iso }}=1.2 U_{\text {eq }}$ (C) for $\mathrm{CH}_{3}$. N-H protons were found from the difference map and either freely refined or fixed to the attached atoms with $U_{\mathrm{H}}$ $=1.2 U_{\mathrm{N}}$.

\section{General procedure for the synthesis of ligands 1-5}

Pyridyl amine $(1 \mathrm{mmol})$ was treated with the appropriate isothiocyanate $(1.1 \mathrm{mmol})$ in $20 \mathrm{ml}$ acetonitrile. Reactions were carried out in a microwave reactor for $40 \mathrm{~min}$ at $100{ }^{\circ} \mathrm{C}$. The resulting reaction mixture was gravity filtered and slow evaporation of the solvents yielded amorphous powers and crystalline samples in the case of 1,3 and 4 . Thiourea 5 was obtained as pale yellow coloured powder after column chromatography. Thioureas 1-5 were recrystallised using hot acetonitrile.

1: Red crystals were obtained from acetonitrile. Yield $=180$ $\mathrm{mg}(68 \%) .{ }^{1} \mathrm{H}$ NMR (400 MHz, DMSO- $\left.d_{6}\right): 10.31(\mathrm{~s}, 1 \mathrm{H}), 10.13$ $(\mathrm{s}, 1 \mathrm{H}), 8.67$ (s, 1H), 8.20-8.14 (m, 3H), 7.90-8.06 (m, 2H), 7.68$7.20(\mathrm{~m}, 1 \mathrm{H}), 6.85(\mathrm{~s}, 1 \mathrm{H})$, and $6.66(\mathrm{~d}, 1 \mathrm{H}, J=8 \mathrm{~Hz}) \cdot{ }^{13} \mathrm{C} \mathrm{NMR}$ (400 MHz, DMSO- $d_{6}$ ): 180.92, 158.88, 147.69, 145.78, 143.06, 137.86, 124.15, 123.52, 116.06 and 107.51. IR $\left(\mathrm{cm}^{-1}\right): 3293.9$, 3153.2, 2915.6, 1591.8, 1544.9, 1448.9, 1499.6, 1329.4, 1268.9, 1109.8, 991.5, 857.9 and 744.8. HRMS calcd. for $\mathrm{C}_{12} \mathrm{H}_{12} \mathrm{~N}_{5} \mathrm{O}_{2} \mathrm{~S}=$ 290.0712; found mass $=290.0712$. Elemental analysis calcd. for $\mathrm{C}_{12} \mathrm{H}_{11} \mathrm{~N}_{5} \mathrm{O}_{2} \mathrm{~S}: \mathrm{C}, 49.82 ; \mathrm{H}, 3.83 ; \mathrm{N}, 24.21$. Found: $\mathrm{C}, 49.83 ; \mathrm{H}$, 3.85; N, 24.33. Melting point: $169.1-169.3{ }^{\circ} \mathrm{C}$.

2: Trituration was performed to remove trace amounts of an impurity from the white coloured powder. White crystals were obtained by slow evaporation of acetonitrile. Yield $=142 \mathrm{mg}$ (59.1\%). ${ }^{1} \mathrm{H}$ NMR (400 MHz, DMSO- $d_{6}$ ): $9.88(\mathrm{~s}, 1 \mathrm{H}), 9.75$ (s, $1 \mathrm{H}), 8.55(\mathrm{~s}, 1 \mathrm{H}), 8.16(\mathrm{~m}, 1 \mathrm{H}), 7.66-7.62(\mathrm{~m}, 1 \mathrm{H}), 7.52-7.49(\mathrm{~m}$, 2H), 7.17-7.10 (m, 2H), 6.84-6.81 (m, 1H), 6.66-6.64 (m, 1H). ${ }^{13} \mathrm{C}$ NMR (400 MHz, DMSO- $d_{6}$ ): 182.02, 160.94, 159.64, 158.54, $148.11,138.24,136.05,127.96,116.20,115.03,114.80$ and 107.63. IR ( $\left.\mathrm{cm}^{-1}\right): 3146.7,2942,1603,1579,1542.5,1507.6$, 1412.3, 1444.2, 1412.3, 1351.5, 1289.3, 1262.4, 1215.6, 1149.9, 1126.9, 1087.0, 992.7, 925.2, 835.5, 819.8, 766.4 and 732.3. HRMS calcd. for $\mathrm{C}_{12} \mathrm{H}_{12} \mathrm{~N}_{4} \mathrm{FS}=263.0767$, found $=263.0766$. $\mathrm{C}_{12} \mathrm{H}_{11} \mathrm{FN}_{4} \mathrm{~S}$ : C, 54.95; H, 4.23; N, 21.36. Found: C, 54.50; H, 4.10; N, 21.07. Melting point: $162.5-162.7{ }^{\circ} \mathrm{C}$.

3: Slow evaporation of the reaction mixture for $\sim 16 \mathrm{~h}$ yielded white coloured crystals. Yield $=152 \mathrm{mg}(60.9 \%) .{ }^{1} \mathrm{H}$ NMR (400 MHz, DMSO- $\left.d_{6}\right): 9.61$ (s, 1H), 9.44 (s, 1H), 8.61 (s, $1 \mathrm{H}), 8.13-8.14(\mathrm{~d}, 1 \mathrm{H}, J=4 \mathrm{~Hz}), 7.65(\mathrm{t}, J=8 \mathrm{~Hz}, 1 \mathrm{H}), 7.01-7.08$ $(\mathrm{m}, 3 \mathrm{H}), 6.81(\mathrm{t}, J=8 \mathrm{~Hz}, 1 \mathrm{H}), 6.67-6.69(\mathrm{~d}, J=8 \mathrm{~Hz}, 1 \mathrm{H})$ and $2.14(\mathrm{~s}, 6 \mathrm{H}) .{ }^{13} \mathrm{C}$ NMR (400 MHz, DMSO- $\left.d_{6}\right): 181.82,159.47$, 147.64, 137.69, 137.18, 136.36, 127.43, 126.55, 115.49, 106.77 and 18.06. IR $\left(\mathrm{cm}^{-1}\right): 3289.5,3138.3,2920.0,1583.45,1506.93$,
1451.8, 1300.6, 1255.1, 1122.7, 1081.4, 996.6, 931.2, 812.2, 769.8 and 738.9. HRMS calcd. for $\mathrm{C}_{14} \mathrm{H}_{17} \mathrm{~N}_{4} \mathrm{~S}=273.1174$, found mass $=273.1161$. Elemental analysis calcd. for $\mathrm{C}_{14} \mathrm{H}_{16} \mathrm{~N}_{4} \mathrm{~S}: \mathrm{C}$, 54.50; H, 4.10; N, 21.07. Found: C, 54.95; H, 4.23; N, 21.36. Melting point: $193.1-193.4{ }^{\circ} \mathrm{C}$.

4: Pale yellow crystals. Yield $=210 \mathrm{mg}(93 \%) .{ }^{1} \mathrm{H}$ NMR $(400$ MHz, DMSO- $\left.d_{6}\right): 10.06(\mathrm{~s}, 1 \mathrm{H}), 9.94(\mathrm{~s}, 1 \mathrm{H}), 8.62(\mathrm{~s}, 2 \mathrm{H}), 8.31$ $(\mathrm{d}, 1 \mathrm{H}, J=4 \mathrm{~Hz}), 8.16(\mathrm{~d}, 1 \mathrm{H}, J=8.4 \mathrm{~Hz}), 7.94(\mathrm{~d}, 1 \mathrm{H}, J=7.5 \mathrm{~Hz})$, $7.65(\mathrm{t}, 1 \mathrm{H}, J=14.8 \mathrm{~Hz}), 7.35(\mathrm{dd}, 1 \mathrm{H}, J=8.0 \mathrm{~Hz}), 6.83(\mathrm{t}, 1 \mathrm{H}, J=$ $12 \mathrm{~Hz}$ ), 6.66 (d, $1 \mathrm{H}, J=8 \mathrm{~Hz}) .{ }^{13} \mathrm{C}$ NMR (400 MHz, DMSO- $\left.d_{6}\right)$ : 182.27, 159.49, 148.14, 147.23, 145.97, 138.34, 136.53, 133.44, 123.19, 116.37 and 107.74. IR $\left(\mathrm{cm}^{-1}\right): 3137.05,2962.72$, $1601.82,1579.18,1515.91,1547.26,1453.72,1424.70$, 1287.84, 1265.78, 1233.48, 1192.07, 1087.79, 1027.28, 825.64, 770.91 and 707.96. Elemental analysis calcd. for $\mathrm{C}_{11} \mathrm{H}_{11} \mathrm{~N}_{5} \mathrm{~S}: \mathrm{C}$, 53.86; H, 4.52; N, 28.55. Found: C, 53.82; H, 4.33; N, 28.59. HRMS calcd. for $\mathrm{C}_{11} \mathrm{H}_{10} \mathrm{~N}_{5} \mathrm{~S}$ : 244.0665, found mass: 244.0657 . Melting point: $188.6-188.9{ }^{\circ} \mathrm{C}$.

5: Pale yellow amorphous powder: Yield: $74.2 \%(212 \mathrm{mg}) \cdot{ }^{1} \mathrm{H}$ NMR (400 MHz, DMSO- $\left.d_{6}\right): 10.14(\mathrm{~S}, 1 \mathrm{H}), 9.97(\mathrm{~S}, 1 \mathrm{H}), 8.63$ (S, $1 \mathrm{H}), 8.15(\mathrm{~S}, 1 \mathrm{H}), 7.85(\mathrm{~d}, 2 \mathrm{H}, J=8 \mathrm{~Hz}), 7.66(\mathrm{~d}, 3 \mathrm{H}, J=12 \mathrm{~Hz})$, $6.84(\mathrm{~s}, 1 \mathrm{H})$ and $6.66(\mathrm{~d}, 1 \mathrm{H}, J=8 \mathrm{~Hz}) \cdot{ }^{13} \mathrm{C} \mathrm{NMR}(400 \mathrm{MHz}$, DMSO- $\left.d_{6}\right)$ : $181.14,159.01,147.68,143.06,137.84,125.72$, 125.08, 124.89, 124.40, 123.01, 115.93 and 107.35. HRMS calcd. for $\mathrm{C}_{13} \mathrm{H}_{12} \mathrm{~N}_{4} \mathrm{~F}_{3} \mathrm{~S}$ : 313.0735. Found: 313.0723. Melting point: $184.7-184.9{ }^{\circ} \mathrm{C}$. IR $\left(\mathrm{cm}^{-1}\right)$ : $3136.10,2923.2,1600.7$, 1585.3, 1523.5, 1505.1, 1451.1, 1321.8, 1294.6, 1164.8, 1102.3, 1064.5, 992.3, 845.5, 791.4, 776.7, 731.4, 658.0.

\section{Synthesis of $\mathrm{Zn}$ (II) complexes 6 and 7}

Synthesis of 6. To a well stirred solution of thiourea $1(0.16$ $\mathrm{mmol})$ in acetonitrile was added $\mathrm{Zn}\left(\mathrm{NO}_{3}\right)_{2}(0.16 \mathrm{mmol})$. On the addition of the $\mathrm{Zn}$ (II) salt, a red colouration appeared and the solution was heated to reflux for $16 \mathrm{~h}$. The reaction mixture was filtered and the filtrate left to evaporate over 24 hours. Micro crystalline 6 was isolated after the slow evaporation of acetonitrile. These crystals were not good enough for diffraction analysis. The microcrystalline 6 was dissolved in DMF which on slow evaporation yielded X-ray quality red crystals of 6 over a $24-48 \mathrm{~h}$ period. $61 \%$ (w.r.t ligand 1). HRMS calcd. for $\mathrm{C}_{24} \mathrm{H}_{19} \mathrm{~N}_{10} \mathrm{O}_{4} \mathrm{~S}_{2} \mathrm{Zn:}$ 639.0324. Found: 639.0333. ${ }^{1} \mathrm{H}$ NMR (600 MHz, DMSO- $d_{6}$ ): 10.97 (d, $\left.1 \mathrm{H}, J=6 \mathrm{~Hz}\right), 9.58(\mathrm{~S}, 2 \mathrm{H}), 8.15$ (d, $J=$ $12 \mathrm{~Hz}, 2 \mathrm{H}), 7.84$ (d, $J=6 \mathrm{~Hz}, 2 \mathrm{H}), 7.53$ (t, 1H, $J=12 \mathrm{~Hz}), 7.3-$ $7.27(\mathrm{~m}, 1 \mathrm{H}), 6.63(\mathrm{~d}, 1 \mathrm{H}, J=6 \mathrm{~Hz})$ and $6.63(\mathrm{t}, 1 \mathrm{H}, J=12 \mathrm{~Hz})$. Elemental analysis calcd. for $\mathrm{C}_{27} \mathrm{H}_{27} \mathrm{~N}_{11} \mathrm{O}_{5} \mathrm{~S}_{2} \mathrm{Zn}$ : C, 45.35; $\mathrm{H}$, 3.81; N, 21.55. Found: C, 45.02; H, 3.06; N, 21.38. IR $\left(\mathrm{cm}^{-1}\right)$ : 3257.7, 1665.0, 1637.7, 1525.8, 1560.5, 1586.9, 1495.2, 1470.7, 1315.9, 1297.2, 1261.8, 1158.5, 1059.1, 992.6, 846.7, 736.04 and 675.6.

Synthesis of 7 . To a well stirred solution of $5(0.16 \mathrm{mmol})$ in acetonitrile, was added $\mathrm{Zn}\left(\mathrm{NO}_{3}\right)_{2}(0.16 \mathrm{mmol})$. As soon as the addition of the $\mathrm{Zn}$ (II) salt a yellow coloration was observed and the solution was heated to reflux. After $16 \mathrm{~h}$, the reaction mixture was filtered and left to slow evaporation over a $24 \mathrm{~h}$ period. This yielded X-ray quality yellow crystals of $7(33 \mathrm{mg}$, $30 \%$, w.r.t ligand 5). HRMS calcd. for $\mathrm{C}_{26} \mathrm{H}_{19} \mathrm{~N}_{8} \mathrm{~F}_{6} \mathrm{~S}_{2} \mathrm{Zn}$ : 685.0370. Found: 685.0374. IR $\left(\mathrm{cm}^{-1}\right)$ : 3256.7, 1639.60, $1590.96,1492.39,1406.85,1314.56,1256.99,1163.75$, 1095.73, 1054.05, 982.01, 814.90 and 746.71 . 


\section{Acknowledgements}

Financial support from Science Foundation Ireland (SFI RFP 2008 and SFI PI 2010 grants awarded to TG) as well as IRSET Postdoctoral Fellowship (JAK) is greatly acknowledged.

\section{References}

1 (a) J. T. Lenthall, J. A. Foster, K. M. Anderson, M. R. Probert, J. A. K. Howard and J. W. Steed, CrystEngComm, 2011, 13, 3202-3212; (b) J. W. Steed, Chem. Commun., 2011, 47, 1379-1383; (c) J. A. Foster, M. O. M. Piepenbrock, G. O. Lloyd, N. Clarke, J. A. K. Howard and J. W. Steed, Nat. Chem., 2010, 2, 1037-1043; (d) R. Custelcean, Chem. Commun., 2008, 295-307; (e) C. Caltagirone, G. W. Bates, P. A. Gale and M. E. Light, Chem. Commun., 2008, 61-63; (f) L. A. Estroff and A. D. Hamilton, Chem. Rev., 2004, 104, 1201-1217.

2 (a) T. Steiner, Angew. Chem., Int. Ed., 2002, 41, 48-76; (b) G. R. Desiraju, Acc. Chem. Res., 2002, 35, 565-573; (c) V. R. Pedireddi, S. Chatterjee, A. Ranganathan and C. N. R. Rao, J. Am. Chem. Soc., 1997, 119, 10867-10868; (d) C. B. Aakeroy and D. J. Salmon, CrystEngComm, 2005, 7, 439-448; (e) E. Bosch, CrystEngComm, 2007, 9, 191-198; (f) L. S. Evans, P. A. Gale, M. E. Light and R. Quesada, Chem. Commun., 2006, 965-967.

3 (a) C. A. Hunter and J. K. M. Sanders, J. Am. Chem. Soc., 1990, 112, 5525-5534; (b) C. A. Hunter, Chem. Soc. Rev., 1994, 23, 101-109; (c) C. Janiak, J. Chem. Soc., Dalton Trans., 2000, 3885-3896.

4 (a) C. Janiak, S. Temizdemir, S. Dechert, W. Deck, F. Girgsdies, J. Heinze, M. J. Kolm, T. G. Scharmann and O. M. Zipffel, Eur. J. Inorg. Chem., 2000, 1229-1241; (b) E. R. T. Tiekink and J. Zukerman-Schpector, Chem. Commun., 2011, 47, 6623-6625; (c) M. Nishio, Y. Umezawa, K. Honda, S. Tsuboyama and H. Suezawa, CrystEngComm, 2009, 11, 1757-1788.

5 (a) P. A. Gale and T. Gunnlaugsson, Chem. Soc. Rev., 2010, 39, 3595-3596; (b) A.-F. Li, J.-H. Wang, F. Wang and Y.B. Jiang, Chem. Soc. Rev., 2010, 39, 3729-3745; (c) R. M. Duke, E. B. Veale, F. M. Pfeffer, P. E. Kruger and T. Gunnlaugsson, Chem. Soc. Rev., 2010, 39, 3936; (d) J. R. Hiscock, P. A. Gale, N. Lalaoui, M. E. Light and N. J. Wells, Org. Biomol. Chem., 2012, 10, 7780-7788; (e) P. A. Gale, J. R. Hiscock, N. Lalaoui, M. E. Light, N. J. Wells and M. Wenzel, Org. Biomol. Chem., 2012, 10, 5909-5915; $(f)$ G. O. Lloyd and J. W. Steed, Nat. Chem., 2009, 1, 437-442; (g) C. B. Aakeroy, S. V. Panikkattu, B. DeHaven and J. Desper, Cryst. Growth Des., 2012, 12, 2579-2587; $(h)$ R. Custelcean, D. Jiang, B. P. Hay, W. Luo and B. Gu, Cryst. Growth Des., 2008, 8, 1905-1915.

6 (a) G. R. Desiraju, Angew. Chem., Int. Ed., 1995, 34, 2311-2327; (b) M. Wenger and J. Bernstein, Angew. Chem., Int. Ed., 2006, 45, 7966-796; (c) C. B. Aakeroy and K. R. Seddon, Chem. Soc. Rev., 1993, 22, 397-407; (d) G. R. Desiraju, Angew. Chem., Int. Ed., 2007, 46, 8342-8356; (e) C. B. Aakeroy, N. R. Champness and C. Janiak, CrystEngComm, 2010, 12, 22-43; (f) P. Byrne, G. O. Lloyd, L. Applegarth, K. M. Anderson, N. Clarke and J. W. Steed, New J. Chem., 2010, 34, 2261-2274.
7 (a) B. A. Blight, C. A. Hunter, D. A. Leigh, H. McNab and P. I. T. Thomson, Nat. Chem., 2011, 3, 244-248; (b) P. S. Corbin, S. C. Zimmerman, P. A. Thiessen, N. A. Hawryluk and T. J. Murray, J. Am. Chem. Soc., 2001, 123, 10475-10488.

8 (a) K. Kumamoto, Y. Misawa, S. Tokita, Y. Kubo and H. Kotsuki, Tetrahedron Lett., 2002, 43, 1035-1038; (b) J. T. Lenthall, J. A. Foster, K. M. Anderson, M. R. Probert, J. A. K. Howard and J. W. Steed, CrystEngComm, 2011, 13, 3202-3212.

9 (a) T. K. Venkatachalam, S. Qazi, P. Samuel and F. M. Uckun, Bioorg. Med. Chem., 2003, 11, 1095-1105; (b) T. K. Venkatachalam and F. M. Uckun, Synth. Commun., 2004, 34, 2451-2461.

10 (a) F. W. Bell, A. S. Cantrell, M. Hoegberg, S. R. Jaskunas, N. G. Johansson, C. L. Jordan, M. D. Kinnick, P. Lind and J. M. Morin, J. Med. Chem., 1995, 38, 4929-4936; (b) S. B. Tsogoeva, M. J. Hateley, D. A. Yalalov, K. Meindl, C. Weckbecker and K. Huthmacher, Bioorg. Med. Chem., 2005, 13, 5680-5685.

11 (a) W.-X. Liu, R. Yang, A.-F. Li, Z. Li, Y.-F. Gao, X.-X. Luo, Y.B. Ruan and Y.-B. Jiang, Org. Biomol. Chem., 2009, 7, 4021-4028; (b) Z. Li, F.-Y. Wu, L. Guo, A.-F. Li and Y.B. Jiang, J. Phys. Chem. B, 2008, 112, 7071-7079; (c) F.Y. Wu, Z. Li, L. Guo, X. Wang, M.-H. Lin, Y.-F. Zhao and Y.B. Jiang, Org. Biomol. Chem., 2006, 4, 624-630; (d) S. Rashdan, M. E. Light and J. D. Kilburn, Chem. Commun., 2006, 4578-4580; (e) S. Rossi, G. M. Kyne, D. L. Turner, N. J. Wells and J. D. Kilburn, Angew. Chem., Int. Ed., 2002, 41, 4233-4236.

12 (a) Y. Takemoto, Org. Biomol. Chem., 2005, 3, 4299-4306; (b) M. P. Lalonde, Y. Chen and E. N. Jacobsen, Angew. Chem., Int. Ed., 2006, 45, 6366-6370; (c) S. B. Tsogoeva and S. Wei, Chem. Commun., 2006, 1451-1453.

13 (a) E. B. Veale, G. M. Tocci, F. M. Pfeffer, P. E. Kruger and T. Gunnlaugsson, Org. Biomol. Chem., 2009, 7, 3447; (b) C. M. G. dos Santos and T. Gunnlaugsson, Dalton Trans., 2009, 4712; (c) E. B. Veale and T. Gunnlaugsson, J. Org. Chem., 2008, 73, 8073; (d) C. M. G. dos Santos, T. McCabe and T. Gunnlaugsson, Tetrahedron Lett., 2007, 48, 3135; (e) J. A. Kitchen, E. M. Boyle and T. Gunnlaugsson, Inorg. Chim. Acta, 2012, 381, 236-242; $(f)$ F. M. Pfeffer, P. E. Kruger and T. Gunnlaugsson, Org. Biomol. Chem., 2007, 5, 1894; $(g)$ E. Quinlan, S. E. Matthews and T. Gunnlaugsson, J. Org. Chem., 2007, 72, 7497.

14 (a) F. M. Pfeffer, P. E. Kruger and T. Gunnlaugsson, Org. Biomol. Chem., 2007, 5, 1894-1902; (b) E. B. Veale, G. M. Tocci, F. M. Pfeffer, P. E. Kruger and T. Gunnlaugsson, Org. Biomol. Chem., 2009, 7, 3447-3454; (c) E. M. Boyle, T. McCabe and T. Gunnlaugsson, Supramol. Chem., 2010, 22, 586-597; (d) R. M. Duke and T. Gunnlaugsson, Tetrahedron Lett., 2007, 48, 8043-8047; (e) T. Gunnlaugsson, A. P. Davis, J. E. O'Brien and M. Glynn, Org. Biomol. Chem., 2005, 3, 48-56; $(f)$ T. Gunnlaugsson, M. Glynn, G. M. Tocci (née Hussey), P. E. Kruger and F. M. Pfeffer, Coord. Chem. Rev., 2006, 250, 3094; $(g)$ C. M. G. dos Santos, T. McCabe, G. W. Watson, P. E. Kruger and T. Gunnlaugsson, J. Org. Chem., 2008, 73, 9235.

15 (a) T. Gunnlaugsson, P. E. Kruger, P. Jensen, J. Tierney, H. D. P. Ali and M. G. Hussey, J. Org. Chem., 2005, 70, 10875; 
(b) H. D. P. Ali, P. E. Kruger and T. Gunnlaugsson, New J. Chem., 2008, 32, 1153.

16 (a) R. M. Duke, T. McCabe, W. Schmitt and T. Gunnlaugsson, J. Org. Chem., 2012, 77, 3115-3126; (b) R. M. Duke, J. E. O'Brien, T. McCabe and T. Gunnlaugsson, Org. Biomol. Chem., 2008, 6, 4089.

17 (a) R. Alonso, E. Bermejo, R. Carballo, A. Castineiras and T. Perez, J. Mol. Struct., 2002, 606, 155-173; (b) A. Saxena and R. Pike, J. Chem. Crystallogr., 2007, 37, 755-764; (c) H. Sun, H. Mei, G. An, J. Han and Y. Pan, CrystEngComm, 2011, 13, 734-737.

18 (a) A. D. Burrows, S. Menzer, D. Michael, P. Mingos, A. J. P. White and D. J. Williams, J. Chem. Soc., Dalton Trans., 1997, 4237-4240; (b) G. V. Romanenko, L. I. Myachina and S. V. Larionov, J. Struct. Chem., 2001, 42, 322-325; (c) J. E. V. Babb, A. D. Burrows, R. W. Harrington and M. F. Mahon, Polyhedron, 2003, 22, 673-686; (d) M. T. Allen, A. D. Burrows and M. F. Mahon, J. Chem. Soc., Dalton Trans., 1999, 215-221.

19 (a) A. D. Burrows, R. W. Harrington, M. F. Mahon and S. J. Teat, Eur. J. Inorg. Chem., 2003, 766-776; (b) A. D. Burrows, R. W. Harrington and M. F. Mahon, CrystEngComm, 2000, 2, 77-81.

20 A. D. Burrows, R. W. Harrington, M. F. Mahon and S. J. Teat, CrystEngComm, 2002, 4, 813-822.

21 (a) F. A. Saad, N. J. Buurma, A. J. Amoroso, J. C. Knight and B. M. Kariuki, Dalton Trans., 2012, 41, 4608-4617; (b) G. Li, D.-J. Che, Z.-F. Li, Y. Zhu and D.-P. Zou, New J. Chem., 2002, 26, 1629-1633.

22 (a) G. G. Sadikov, A. S. Antsyshkina, T. V. Koksharova, V. S. Sergienko, S. V. Kurando and I. S. Gritsenko, Crystallogr. Rep., 2012, 57, 528-540; (b) L. J. Wei, H. L. Gao and J. Z. Cui, Phosphorus, Sulfur Silicon Relat. Elem., 2012, 187, 1101-1108; (c) S. B. Novakovic, G. A. Bogdanovic, B. Fraisse, N. E. Ghermani, N. Bouhmaida and A. S. D. Bire, J. Phys. Chem. A, 2007, 111, 13492-13505.

23 (a) L. S. Reddy, S. Basavoju, V. R. Vangala and A. Nangia, Cryst. Growth Des., 2006, 6, 161-173; (b) D. R. Turner, B. Smith, E. C. Spencer, A. E. Goeta, I. R. Evans, D. A. Tocher, J. A. K. Howarda and J. W. Steed, New J. Chem., 2005, 29, 90-98; (c) N. Qureshi, D. S. Yufit, J. A. K. Howard and J. W. Steed, Dalton Trans., 2009, 5708-5714; (d)
P. Blondeau, A. van der Lee and M. Barboiu, Inorg. Chem., 2005, 44, 5649-5653; (e) R. W. Troff, R. Hovorka, T. Weilandt, A. Lützen, M. Cetina, M. Nieger, D. Lentz, K. Rissanen and C. A. Schalley, Dalton Trans., 2012, 41, 8410-8420.

24 J. T. Lenthall, J. A. Foster, K. M. Anderson, M. R. Probert, J. A. K. Howard and J. W. Steed, CrystEngComm, 2011, 13, 3202-3212.

25 A. Saxena and R. D. Pike, J. Chem. Crystallogr., 2007, 37, 755.

26 S. Rashdan, M. E. Light and J. D. Kilburn, Chem. Commun., 2006, 4578-4580.

27 S. I. Orysyk, V. V. Bon, O. O. Obolentseva, Y. L. Zborovskii, V. V. Orysyk, V. I. Pekhnyo, V. I. Staninets and V. M. Vovk, Inorg. Chim. Acta, 2012, 382, 127-138.

28 (a) X. Shen, X. Shi, B. Kang, Y. Liu, Y. Tong, H. Jiang and K. Chen, Polyhedron, 1998, 17, 4049-4058; (b) M. MartinezCalvo, M. J. Romero, R. Pedrido, A. M. Gonzalez-Noya, G. Zaragoza and M. R. Bermejo, Dalton Trans., 2012, 41, 13395-13404.

29 (a) K. D. M. Harris, Chem. Soc. Rev., 1997, 26, 279-289; (b) K. D. M. Harris, Supramol. Chem., 2007, 19, 47-53; (c) B. A. Palmer, B. M. Kariuki, V. K. Muppidi, C. E. Hughes and K. D. M. Harris, Chem. Commun., 2011, 47, 3760-3762.

30 J. M. Roberts, B. M. Fini, A. A. Sarjeant, O. K. Farha, J. T. Hupp and K. A. Scheidt, J. Am. Chem. Soc., 2012, 134, 3334.

31 (a) R. V. Afonso, J. Durão, A. Mendes, A. M. Damas and L. Gales, Angew. Chem., Int. Ed., 2010, 49, 3034-3036; (b) W. Yang, A. Greenaway, X. Lin, R. Matsuda, A. J. Blake, C. Wilson, W. Lewis, P. Hubberstey, S. Kitagawa, N. R. Champness and M. Schroder, J. Am. Chem. Soc., 2010, 132, 14457-14469; (c) A. Comotti, S. Bracco, G. Distefano and P. Sozzani, Chem. Commun., 2009, 284-286.

32 (a) J. Tian, P. K. Thallapally and B. P. McGrail, CrystEngComm, 2012, 14, 1909-1919; (b) L. J. Barbour, Chem. Commun., 2006, 1163-1168.

33 W. Xu, F. Jiang, Y. Zhou, K. Xiong, L. Chen, M. Yang, R. Feng and M. Hong, Dalton Trans., 2012, 41, 7737-7745.

34 G. M. Sheldrick, Acta Crystallogr., Sect. A: Found. Crystallogr., 2008, A64, 112. 